\title{
Emmanuel Ma Mung, La Diaspora chinoise, géographie d'une migration
}

Paris, Ophrys, 2000, 176 p.

Eric Guerassimoff et Carine Pina-Guerassimoff

\section{(2) OpenEdition}

\section{Journals}

Édition électronique

URL : http://journals.openedition.org/chinaperspectives/783

DOI : $10.4000 /$ chinaperspectives. 783

ISSN : 1996-4617

\section{Éditeur}

Centre d'étude français sur la Chine contemporaine

Édition imprimée

Date de publication : 1 décembre 2003

ISSN : 2070-3449

\section{Référence électronique}

Eric Guerassimoff et Carine Pina-Guerassimoff, «Emmanuel Ma Mung, La Diaspora chinoise, géographie d'une migration », China Perspectives [En ligne], 50 | november- december 2003, mis en ligne le 20 avril 2007, consulté le 21 septembre 2020. URL : http://journals.openedition.org/ chinaperspectives/783 ; DOI : https://doi.org/10.4000/chinaperspectives.783

Ce document a été généré automatiquement le 21 septembre 2020

(c) All rights reserved 


\title{
Emmanuel Ma Mung, La Diaspora chinoise, géographie d'une migration
}

\author{
Paris, Ophrys, 2000, 176 p.
}

\author{
Eric Guerassimoff et Carine Pina-Guerassimoff
}

\section{NOTE DE L'ÉDITEUR}

Translated from the French original by Philip Liddell

1 In France, the addition of "China and the Chinese Diaspora" to history and geography syllabuses for the CAPES and Agrégation courses has opened the way for the prompt publication of books aimed at non-specialists. The widening of the proposed subjectmatter has led most of these studies-of very unequal craftsmanship-to concentrate on the geographical aspects of China and to deal only peripherally with the question of the "Chinese of the Diaspora"; this strengthens the impression that the subject matter is too wide and that the question itself, as initially set, has been misunderstood. While most of these publications have been reviewed, one of them has passed-unjustlyalmost unnoticed, by non-specialists at any rate.

2 Emmanuel Ma Mung is a geographer; he is the Director of Research at the Centre national de la recherche scientifique (CNRS) and the Director of the Migrinter Laboratory. The book he has written is both a generalised presentation of Chinese migration and a highly topical reflection on the process whereby it has been transformed into the diaspora. The book, divided into eight parts and three chapters, has the immediate merit of offering an overall picture, in space and time, of the Chinese migrations, taking into account both the original homeland (mainland China) and the areas where migrants first arrived or where they re-emigrated from. In this regard, Ma Mung's study completes and updates the only generalised work of reference 
so far available in France: the Que sais-je volume (PUF) by Pierre Trolliet, La Diaspora chinoise.

3 The first part, "Chinese International Migrations", starts with a very brief history of Chinese migration, reminding us of the diachronic significance of the phenomenon. The writer goes on to place the present-day movements of Chinese people (and/or people of Chinese origin) within the general context, on a complex and worldwide scale, of international migration. He also recalls (p. 22) that the dynamic of Chinese migratory flows rests primarily on networks or trafficking organisations, as with the Qingtian migrations into Europe. Emphasising the complex status (political, administrative and cultural) of those grouped together under the term "overseas Chinese", he adopts the (debatable) categorisations of "overseas Chinese" (huaqiao and huaren) suggested by Wang Gungwu ${ }^{1}$.

4 Regrettably, however, the writer subscribes to a hypothesis according to which the various groups "share more and more between them so that the distinctions tend to become blurred; and their connections, mainly trading links at the start, become diversified at all levels and increasingly overlapping" (p. 29). One would not deny that connections do exist, but their general application as called for by Professor Wang is at present no more than a working hypothesis, one with little corroboration from empirical studies. The chapter closes with a swift presentation of the "new categories of migrants", including the skilled migrants, and with a description of the illegal methods of leaving one country and entering another as practised by a growing number of Chinese people from the People's Republic. The second chapter gives a general outline of the main places of origin of Chinese migrants in China and SouthEast Asia, along with Peking's policy on emigrant communities since 1978.

In the second part of the book, "The Chinese Diaspora across the World", the writer gives a survey of present condition of Chinese communities in their host countries (South-East Asia, North and South America, Europe, archipelagos, and Africa). The author rightly stresses the difficulties encountered in calculating the number of "overseas Chinese". In addition to the weaknesses of national statistical services, in trying to assess nationality and levels of assimilation, researchers find themselves up against the complexity and diversity of administrative and cultural status affecting people of Chinese origin. A significant number no longer see themselves specifically as "overseas Chinese" (huaqiao) and are unwilling to be counted as such. They have quite often been settled in their host countries for several generations; and they claim the status of nationals and of full members of their local communities. In South-East Asia, they have often been pushed into this position by local governments that deny, for political reasons, the existence of such categories. These difficulties explain why the only world population count is still today that of Poston (1994) ${ }^{2}$. The second part ends with a detailed chapter devoted to the Chinese presence in Europe. The space given to Italy, Spain and the countries of the former communist bloc underlines the present-day importance of Europe as destination for new Chinese migrants. It is a pity, even so, that the maps offered, notably the one for France (1990), should be so out-of-date. Since the book was published, several national and European monographs have completed the data used by the author, confirming the significance of this destination ${ }^{3}$.

6 The book's originality becomes more evident in the third part, "The Organisation of the Chinese Diaspora". According to Ma Mung, the Chinese diaspora is structured around an entrepreneurial centre: its activities, he says, are "strongly connected" to an 
"economic organisation in which the dimension of identity is predominant" (p. 117). The empirical data used by the author are drawn mainly from surveys carried out in France on the activities of Chinese enterprises (chapter 7). He describes the economic organisation as "consistent", this being shown by the significance of the links between businesses, these being of fundamentally ethnic character (p. 119). The lack of comparisons tends, nevertheless, to restrict the possibility of generalising from the French case. The chapter ends with a presentation of the spatial layout of the Chinese businesses, mainly in the Paris region.

7 The writer pursues his argument by speculating, in chapter 8 , on what it is that qualifies the Chinese migration as a diaspora. He postulates that the diaspora (the dispersal of a society into a multiplicity of places) presents two morphological characters: the multipolarity of the migration and the interpolarity of the connections. It maintains its consistence thanks to a particular conception of extra-territoriality, "that is to say a particular form of self-representation in space" (p. 147). This space, he asserts, is fantasised; it is imaginary; it is utopian. It emerges from the consciousness that the diaspora has of its own dispersal with, as the main consequence, a reticular vision of the relationships and spaces in which human support predominates. Culture and society become a "territory" of unification.

8 The author adds that the diaspora also has a particular connection in time and space, by constituting a particular memory/history: "This genealogy, through the continuity it creates between individuals living in different countries by offering them a common origin, serves as the basis for forming a transnational ethnic identity (p. 158)." Lastly, he asserts that the spatial dispersal of the diaspora is used as a resource, particularly by forming transnational trading networks. Few examples, regrettably, are provided in support of this theoretical, yet attractive, framework, which seems still to be awaiting empirical studies that might provide a better balance for its constituent elements. But it is no doubt an additional merit of this slim volume for Agrégation students that it sets out prospects for future research.

\section{NOTES}

1. Wang Gungwu, China and the Overseas Chinese, Singapore, Times Academic Press, 1991. 2. Poston D., Mao X. M., Yu M. Y., "The Global Distribution of the Overseas Chinese around 1990", Population and Development Review, Vol. 20, No. 23.

3. Guerassimoff, Carine dir., "Les nouvelles migrations chinoises en Europe au début du XXI ${ }^{\mathrm{e}}$ siècle”, Migrations-Société, Paris, CIEMI, vol. 15, n 89, September-October 2003. Michel Foucher dir., Asies nouvelles, Editions Belin, (cartography with commentaries), pp. 383-386. 